\title{
THE ORIGIN OF INOSITOL IN THE RETE TESTIS FLUID OF THE RAM
}

\author{
ALIYA MIDDLETON AND B. P. SETCHELL \\ Department of Biochemistry, A.R.C. Institute of Animal Physiology, \\ Babraham, Cambridge
}

(Received 1st March 1972, accepted 18th April 1972)

\begin{abstract}
Summary. Inositol is synthesized from blood glucose by the ram testis in vivo, and more of the inositol in rete testis fluid is derived from blood glucose than from blood inositol.

However, the turnover rate of the inositol pool in the rete testis fluid is so slow that steady-state conditions were not reached even during a 6-hr infusion.
\end{abstract}

Glucose-6-phosphate is converted to myo-inositol by rat testes and the enzymes involved appear to be concentrated in the supernatant obtained by high speed centrifuging (Eisenberg, 1967). Setchell, Dawson \& White (1968) showed that a high concentration of inositol is found in ram rete testis fluid (RTF) and experiments have now been done to see whether this inositol was absorbed from the blood or whether it was synthesized by the testis from blood glucose. $\mathrm{D}-\left[\mathrm{U}-{ }^{14} \mathrm{C}\right]$ glucose or $\left[2-{ }^{3} \mathrm{H}\right]$ myo-inositol were infused into a recurrent tarsal vein of two conscious rams for $6 \mathrm{hr}$ (priming doses- 50 and $100 \mu \mathrm{Ci}$, then infusion of 0.55 and $1.1 \mu \mathrm{Ci} / \mathrm{min}$, respectively). Blood samples were taken at $2 \mathrm{hr}$ intervals throughout the infusion. Continuous collections of RTF were made by the technique of Voglmayr, Scott, Setchell \& Waites (1967) as modified by Suominen \& Setchell (1972)).

Plasma samples were deproteinized with 10 vols of $5 \%$ perchloric acid and analysed for glucose with glucose oxidase, using the Boehringer assay method for blood sugar (The Boehringer Corporation, London, Ltd). The remainder of the protein-free filtrate was brought to $\mathrm{pH} 5$ with $5 \mathrm{~N}-\mathrm{KOH}$ at $0^{\circ} \mathrm{C}$, and the precipitate of potassium perchlorate was removed. The supernatant and the untreated RTF were used for inositol assay (Campling \& Nixon, 1954), for total radioactivity counting, (by mixing $1 \mathrm{ml}$ with $10 \mathrm{ml}$ Triton X-100: toluene scintillator solution $1: 2 \mathrm{v} / \mathrm{v}$ ) and for thin layer chromatography on silica gel plates (Merck F254) in butan-1-ol, acetone, acetic acid, water (4:4:1:1). The plates were dried at room temperature and then sprayed with $\mathrm{AgNO}_{3}$ in acetone followed by $0.5 \mathrm{~N}$-ethanolic $\mathrm{NaOH}$ (Trevelyan, Procter \& Harrison, 1950). The stained areas corresponding to glucose and inositol were scraped off the plates and counted in a Nuclear Chicago scintillation counter in $1 \mathrm{ml}$ water +10 $\mathrm{ml}$ Triton X-100/toluene $1: 2 \mathrm{v} / \mathrm{v}$ (the toluene contained $4 \mathrm{~g}$ 2,5-diphenyloxazole [PPO] and $50 \mathrm{mg}$ 1,4-di 2-(5-phenyloxazole) benzene [POPOP] per litre), with correction by channels ratio for quenching. The recovery of inositol 

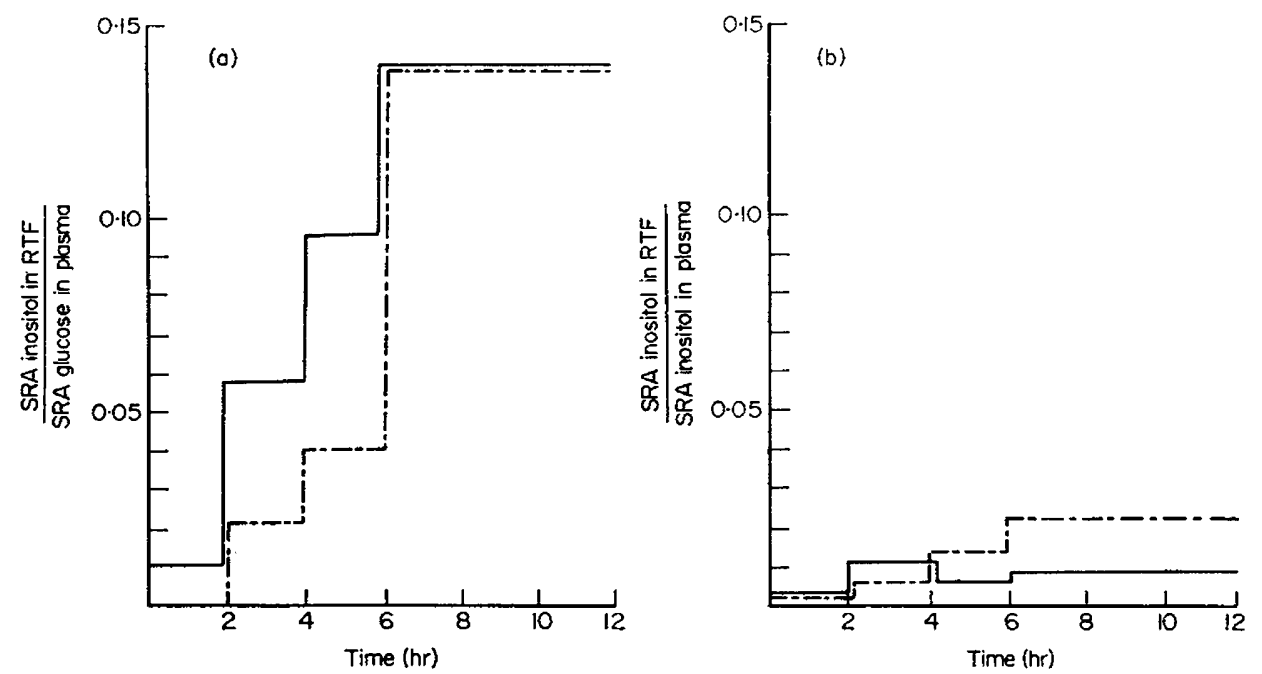

TEXT-FIG. 1. (a) The ratio of the specific radioactivity of RTF inositol to the specific radioactivity of blood plasma glucose during infusion as a function of time, from the beginning of $\left[{ }^{14} \mathrm{C}\right]$ glucose infusion. (b) The ratio of the specific radioactivity of $R T F$ inositol to the specific radioactivity of blood plasma inositol during infusion as a function of time, from the beginning of $\left[{ }^{3} \mathrm{H}\right]$ inositol infusion.,- Ram $1 ; \cdots \cdots$, Ram 2.

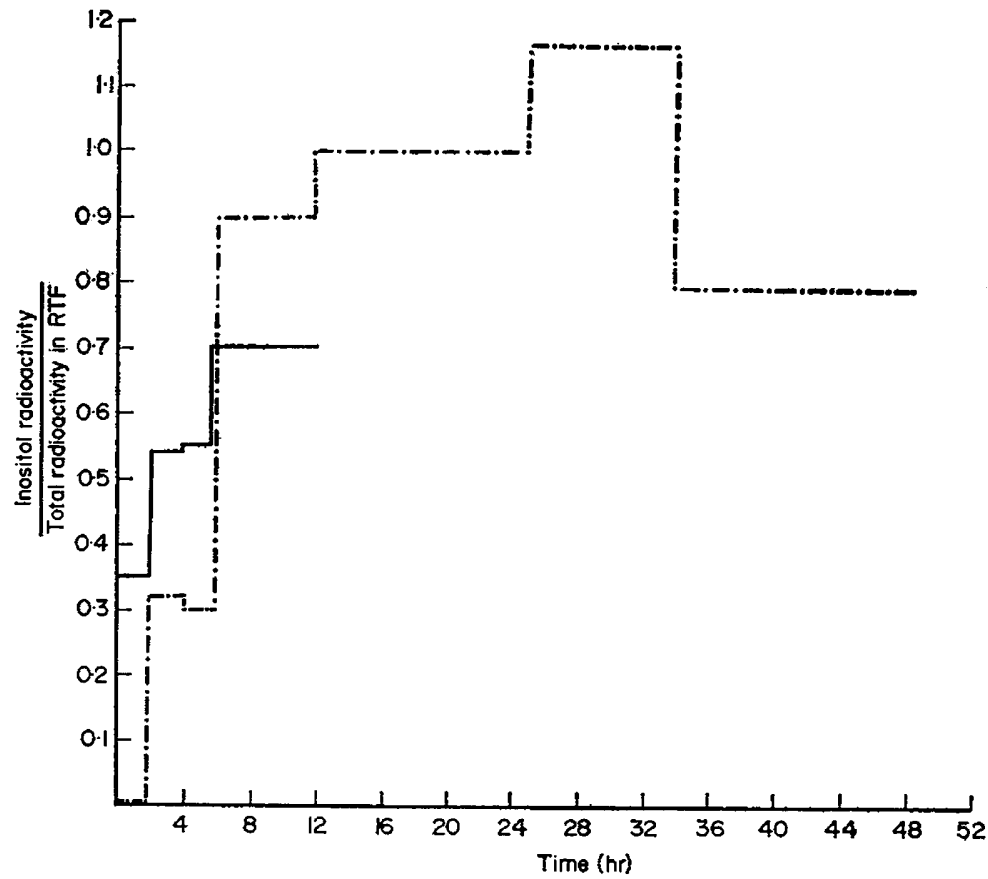

TEXT-FIG. 2. The ratio of the radioactivity in RTF inositol to the total radioactivity in RTF as a function of time from the beginning of $\left[{ }^{14} \mathrm{C}\right]$ glucose infusion.,- Ram 1 ; $-\cdot-\cdot$, Ram 2. 
and glucose standards from the plates was $75 \% \pm 3 \cdot 3$ (ten observations) and $70 \%$ $\pm 5 \cdot 0$ (seven observations).

More radioactivity appears in rete testis fluid inositol after $\left[{ }^{14} \mathrm{C}\right]$ glucose infusion than after $\left[{ }^{3} \mathrm{H}\right]$ inositol infusion (Text-fig. 1). About $8 \mathrm{hr}$ after the beginning of the infusion, the specific radioactivity of RTF inositol was about $14 \%$ of that of blood glucose. When $\left[{ }^{3} \mathrm{H}\right]$ inositol was infused, the specific radioactivity of RTF inositol $8 \mathrm{hr}$ after the beginning of the infusion was only 1 to $2.5 \%$ of that of blood inositol. However, steady-state conditions were not reached and therefore no estimate can be made of the fraction of the RTF inositol that is derived from glucose. It can, nevertheless, be concluded that a considerable part of RTF inositol is made in the testis from blood glucose and a much smaller amount originates from blood inositol.

The radioactivity found in inositol $2 \mathrm{hr}$ after the beginning of $\left[{ }^{14} \mathrm{C}\right]$ glucose infusion accounts for about $30 \%$ of the total radioactivity in the RTF (Text-fig. 2 ). Presumably, the remaining $70 \%$ of the radioactivity is in other metabolites derived from glucose, for example certain amino acids (Setchell, Hinks, Voglmayr \& Scott, 1967). After the end of the infusion, almost all the radioactivity is localized in the inositol and the other radioactive metabolites have disappeared, emphasizing the slow turnover of the inositol. As late as $28 \mathrm{hr}$ after the end of the $\left[{ }^{14} \mathrm{C}\right]$ glucose infusion, there were $1000 \mathrm{~d} / \mathrm{min} / \mathrm{mg}$ inositol in the RTF which is much greater than the specific radioactivity of the blood glucose at that time. Following the infusion of $\left[{ }^{3} \mathrm{H}\right]$ inositol, no consistent difference was found between the total radioactivity in the RTF and that present as inositol. The specific radioactivity of RTF inositol remained constant for $42 \mathrm{hr}$ after the end of the infusion and then fell during the next $24 \mathrm{hr}$.

The enzyme system described by Eisenberg (1967) would, therefore, appear sufficient to account for the production of inositol in the ram testis, but the slow turnover of the inositol pool in the testis and RTF means that it is unlikely that the origin of the inositol can be quantitatively established in vivo.

This work was supported by a grant from the Wellcome Trust.

\section{REFERENCES}

Campling, J. D. \& Nixon, D. A. (1954) The inositol content of foetal blood and foetal fluids. F. Physiol., Lond. 126, 71.

Eisenzerg, F. (1967) D-Myoinositol 1-phosphate product of cyclization of glucose 6-phosphate and substrate for a specific phosphatase in rat testis. 7. biol. Chem. 242, 1375.

Setchell, B. P., Dawson, R. M. C. \& White, R. W. (1968) The high concentration of free myoinositol in rete fluid from rams. J. Reprod. Fert. 17, 219.

Setchell, B. P., Hinks, N. T., Voglmayr, J. K. \& Scotr, T. W. (1967) Amino acids in ram testicular fluid and semen and their metabolism by spermatozoa. Biochem. F. 105, 1061 .

Suominen, J. \& Setchell, B. P. (1972) Enzymes and trypsin inhibitor in rete testis fluid of rams and boars. F. Reprod. Fert. 30, 235.

Trevelyan, W. E., Procter, D. P. \& Harrison, G. S. (1950) Detection of sugars on paper chromatograms. Nature, Lond. 166, 444.

Voglmayr, J. K., Scott, T. W., Setchell, B. P. \& Waites, G. M. H. (1967) Metabolism of testicular spermatozoa and characteristics of testicular fluid collected from conscious rams. F. Reprod. Fert. 14, 87. 